\title{
Research Article \\ Citrus aurantifolia (Christm.) Swingle (lime) Fruit Extract Inhibits the Activities of Polyol Pathway Enzymes
}

\author{
Mutiu Idowu Kazeem*, Habeeb Adebodun Bankole, Tolulope Israel Oladokun, Ahmed Oloruntoba Bello, \\ Monsurah Adenike Maliki
}

Department of Biochemistry, Faculty of Science, Lagos State University, PMB 0001, Ojo, Lagos, Nigeria

\section{ARTICLE INFO}

\section{Article History}

Received 09 June 2020

Accepted 21 August 2020

Keywords

Diabetic complication

lime fruit

aldose reductase

sorbitol dehydrogenase

citrus fruit

\begin{abstract}
Diabetes mellitus is associated with several complications, which may result from one or more factors including increased flux of polyol pathway. This study evaluated the inhibitory potential of four citrus fruits namely Citrus paradisi Macfad. (grape), Citrus limon (L.) Osbeck (lemon), Citrus aurantifolia (Christm.) Swingle (lime) and Citrus sinensis (L.) Osbeck (orange), on the activities of aldose reductase and sorbitol dehydrogenase - the two enzymes that mediate the polyol pathway. This is determined by incubating citrus extracts with appropriate enzymes and substrates. Fruit extract with the lowest half maximal inhibitory concentration $\left(\mathrm{IC}_{50}\right.$ ) was used to assess the mode of inhibition of the enzymes by preparing Lineweaver-Burk plot. Citrus fruits tested inhibited sorbitol dehydrogenase more than aldose reductase, which resulted in lowered $\mathrm{IC}_{50}$ values. Of all the citrus fruits tested, lime fruit extract displayed potent inhibition of aldose reductase $\left(\mathrm{IC}_{50}: 138.66 \mu \mathrm{g} / \mathrm{mL}\right.$ ) and sorbitol dehydrogenase $\left(\mathrm{IC}_{50}: 47.21 \mu \mathrm{g} / \mathrm{mL}\right)$. Kinetic studies also revealed that lime fruit extract inhibited the activities of both enzymes in a competitive manner. In conclusion, the inhibition of the polyol pathway enzymes by the lime fruit extract may be attributed to the presence of phytochemicals such as flavonoids and limonoids.
\end{abstract}

\section{GRAPHICAL ABSTRACT}
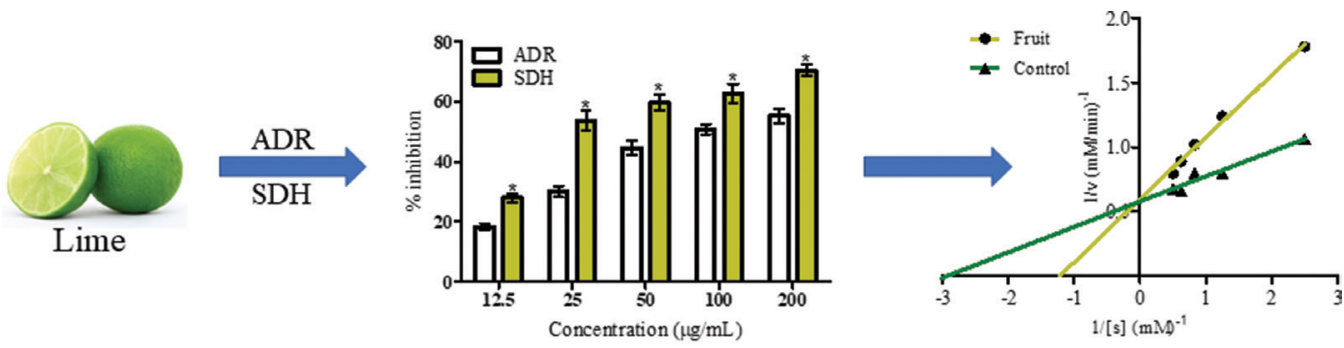

ADR: Aldose reductas

SDH: Sorbitol dehydrogenase

(C) 2020 International Association of Dietetic Nutrition and Safety. Publishing services by Atlantis Press International B.V. This is an open access article distributed under the CC BY-NC 4.0 license (http://creativecommons.org/licenses/by-nc/4.0/).

\section{INTRODUCTION}

The global prevalence of diabetes mellitus has reached an alarming proportion of 463 million and this is projected to increase to 700 million by the year 2045 [1]. A whooping sum of USD 760 billion is spent annually to manage this disease without a complementary reduction in its incidence [1]. Due to its complex nature, diabetes is associated with several complications including nephropathy, neuropathy, retinopathy and cardiovascular diseases [2]. These complications are serious and debilitating, and resulted in the death of 4.2 million people in 2019 [1]. One of the processes implicated in diabetic complications is the polyol pathway.

"Corresponding author. Email: idowu.kazeem@lasu.edu.ng; mikazeem@gmail.com Peer review under responsibility of the International Association of Dietetic Nutrition and Safety
Polyol pathway is an alternative glucose metabolic route which becomes prominent in hyperglycemic condition [3]. Previous studies revealed that this pathway is implicated in diabetic retinopathy and neuropathy $[4,5]$. It is a two-step process in which glucose is reduced to sorbitol and then sorbitol is converted to fructose [6]. Two enzymes are involved in the polyol pathway, namely aldose reductase and sorbitol dehydrogenase $[3,7]$. Since the process cannot proceed without these two enzymes, any entity that is able to inhibit their activities will reduce the flux of this undesirable pathway, and consequently ameliorate diabetic complications.

Recently, there is a renewed interest in natural products especially foods in the management of diseases and one of such group of foods is the citrus fruit [8]. Citrus fruits are important fruit crops worldwide, which are grown mostly in tropical and subtropical regions but consumed in all parts of the globe [8]. They are important 
household fruits which are rich in several phytochemicals, fibre, minerals and vitamins [9]. Though the commonest among these citrus fruits is sweet orange, other citrus fruits include grapefruit, lemon, and lime. Due to their rich phytochemical profiles, citrus fruits provide potential medicinal benefits in addition to their sweet flavour and aroma [10]. One of the diseases speculated to be managed by citrus fruits is diabetes mellitus [8], but how this is achieved remains unknown.

Though, there are previous reports on the antidiabetic potentials of citrus fruits $[8,9]$, there is scarcity of information on their effect on enzymes implicated in diabetic complications. Therefore, the objective of this study is to determine the modulatory potential of four citrus fruits namely grapefruit (Citrus paradisi), lime (Citrus aurantifolia), lemon (Citrus limon) and orange (Citrus sinensis) on diabetic complications - related enzymes. This is by assessing their in vitro inhibitory effect on polyol pathway enzymes (aldose reductase and sorbitol dehydrogenase), and determining their mode(s) of inhibition of the enzymes.

\section{MATERIALS AND METHODS}

\subsection{Chemicals}

Human recombinant aldose reductase (SRP6371), DL-glyceraldehyde, glucose, lithium sulfate, 2-mercaptoethanol, reduced nicotinamide adenine dinucleotide phosphate (NADPH), quercetin, dimethylsulfoxide, sorbitol, sorbitol dehydrogenase, and nicotinamide adenine dinucleotide $\left(\mathrm{NAD}^{+}\right)$were obtained from SigmaAldrich (St. Louis, MO, USA). All other chemicals and solvents were of analytical grade and were obtained from local companies.

\subsection{Sample Collection and Preparation}

Fresh samples of ripe citrus fruits; grape (C. paradisi), lemon (C. limon), lime (C. aurantifolia) and orange (C. sinensis), were obtained from the Fruits store in Ojo Area of Lagos, Nigeria. The fruits were identified and authenticated in the Department of Botany, Lagos State University, Ojo, Lagos. They were peeled and their juice obtained using Juice extractor. The juice was centrifuged $(1500 \mathrm{~g} \times 5 \mathrm{~min})$, filtered and the supernatant freeze-dried in a lyophilizer. Freeze-dried extracts were dissolved in distilled water to give stock solutions of $1.0 \mathrm{mg} / \mathrm{mL}$ and different concentrations $(12.5,25,50,100$ and $200 \mu \mathrm{g} / \mathrm{mL})$ of the extracts were prepared using serial dilution method with distilled water. All extracts were stored at $4^{\circ} \mathrm{C}$ prior to analysis.

\subsection{Aldose Reductase Inhibitory Assay}

The aldose reductase inhibitory assay was performed according to the method of Fatmawati et al. [11] with minor modifications. The reaction mixture contained $0.15 \mathrm{mM} \mathrm{NADPH}, 10 \mathrm{mM}$ DL-glyceraldehyde, $5 \mu \mathrm{L}$ of $100 \mu \mathrm{g} / \mathrm{mL}$ aldose reductase and $100 \mu \mathrm{L}$ of citrus extract $(12.5-200 \mu \mathrm{g} / \mathrm{mL})$ or distilled water in a total volume of $1.0 \mathrm{~mL}$ of $100 \mathrm{mM}$ sodium phosphate buffer ( $\mathrm{pH} \mathrm{6.2).} \mathrm{After} \mathrm{the}$ reaction mixtures were incubated at $25^{\circ} \mathrm{C}$ for $5 \mathrm{~min}$ in advance, the reaction commenced by addition of the enzyme, and then the change in absorbance was measured at $340 \mathrm{~nm}$ after $10 \mathrm{~min}$ using a Cary 50 Bio UV-VIS spectrophotometer (Agilent Technologies, USA). The aldose reductase inhibitory activity was calculated as percentage inhibition, thus;

$$
\% \text { Inhibition }=\left[\frac{\left(\Delta \mathrm{Abs}_{\text {control }}-\Delta \mathrm{Abs}_{\text {extract }}\right)}{\Delta \mathrm{Abs}_{\text {control }}}\right] \times 100
$$

where $\Delta \mathrm{Abs}_{\text {control }}$ and $\Delta \mathrm{Abs}_{\text {extract }}$ represent change in the absorbance of control (water) and extract respectively.

Quercetin was used as positive control in this study while the concentration of extract or quercetin that inhibited $50 \%$ of aldose reductase activities $\left(\mathrm{IC}_{50}\right.$ ) were evaluated using Microsoft Excel (2010).

\subsection{Mode of Inhibition of Aldose Reductase}

The mode of inhibition of aldose reductase by lime extract was performed according to the method described by Dongare et al. [12]. In one set of tubes, the reaction mixture contained $0.15 \mathrm{mM} \mathrm{NADPH}$, DL-glyceraldehyde (10-200 mM), $5 \mu \mathrm{L}$ of $100 \mu \mathrm{g} / \mathrm{mL}$ aldose reductase and $100 \mu \mathrm{L}$ of lime fruit extract $(50 \mu \mathrm{g} / \mathrm{mL})$ in a total volume of $1.0 \mathrm{~mL}$ of $100 \mathrm{mM}$ sodium phosphate buffer ( $\mathrm{pH}$ 6.2). In another set of tubes, $100 \mu \mathrm{L}$ distilled water replaced the lime extract and this serves as control. The change in absorbance was measured at $340 \mathrm{~nm}$ and converted to reaction velocities. Lineweaver-Burk plot was plotted to determine the mode of inhibition.

\subsection{Sorbitol Dehydrogenase Inhibitory Assay}

Sorbitol dehydrogenase activity was determined in accordance with the method of Kobayashi et al. [13]. The assay mixture contained $100 \mathrm{mM}$ Tris-HCl buffer ( $\mathrm{pH} 9.0$ ), $0.5 \mathrm{mM} \mathrm{NAD}^{+}, 50 \mu \mathrm{L}$ of $100 \mu \mathrm{g} / \mathrm{mL}$ sorbitol dehydrogenase, $100 \mathrm{mM}$ sorbitol (substrate) and citrus extract $(12.5-200 \mu \mathrm{g} / \mathrm{mL})$. The reaction was initiated by the addition of $\mathrm{NAD}^{+}$. The rate of change in the absorbance of mixture was measured at $340 \mathrm{~nm}$ using a Cary 50 Bio UV-VIS spectrophotometer. The sorbitol dehydrogenase inhibitory activity was calculated as percentage inhibition, thus;

$$
\% \text { Inhibition }=\left[\frac{\left(\Delta \mathrm{Abs}_{\text {control }}-\Delta \mathrm{Abs}_{\text {extract }}\right)}{\Delta \mathrm{Abs}_{\text {control }}}\right] \times 100
$$

where $\Delta \mathrm{Abs}_{\text {control }}$ and $\Delta \mathrm{Abs}_{\text {extract }}$ represent change in the absorbance of control (water) and extract respectively.

Quercetin was used as positive control in this study while the concentration of extract or quercetin that inhibited $50 \%$ of sorbitol dehydrogenase activities $\left(\mathrm{IC}_{50}\right.$ ) were evaluated using Microsoft Excel (2010).

\subsection{Mode of Inhibition of Sorbitol Dehydrogenase}

The mode of inhibition of sorbitol dehydrogenase by lime fruit extract was performed according to the method described by Lindstad et al. [14]. In one set of tubes, the reaction mixture contained $100 \mathrm{mM}$ tris- $\mathrm{HCl}$ buffer ( $\mathrm{pH} 9.0$ ), $0.5 \mathrm{mM} \mathrm{NAD}^{+}, 50 \mu \mathrm{L}$ of $100 \mu \mathrm{g} / \mathrm{mL}$ sorbitol dehydrogenase, sorbitol (100-500 mM) and 
$50 \mu \mathrm{g} / \mathrm{mL}$ grapefruit extract. In another set of tubes, distilled water replaced the grapefruit extract and this serves as control. The change in absorbance was measured at $340 \mathrm{~nm}$ and converted to reaction velocities. Lineweaver-Burk plot was plotted to determine the mode of inhibition.

\subsection{Statistical Analysis}

All analyses were performed in triplicates unless otherwise stated. Data were expressed as mean \pm Standard Error of the Mean (SEM) and statistical significance was considered at $p<0.05$. IC $\mathrm{C}_{50}$ values were obtained from percentage inhibitions using Microsoft Excel software (Microsoft, 2010). Analysis of variance was used to assess differences in the percentage inhibitions and $\mathrm{IC}_{50}$ values of the extracts as well as standard. Modes of inhibition of enzymes were determined by Linear regression using GraphPad Prism statistical package (GraphPad Software, USA).

\section{RESULTS}

Figure 1 shows the inhibitory effect of selected citrus fruits on the activities of aldose reductase and sorbitol dehydrogenase. At all concentrations tested, the grapefruit and lime extracts produced significantly higher $(p<0.05)$ inhibition of sorbitol dehydrogenase than the aldose reductase (Figure $1 \mathrm{a}$ and $1 \mathrm{c}$ ). For lemon and orange extracts, the percentage inhibition was similar at the lowest concentration $(12.5 \mu \mathrm{g} / \mathrm{mL})$ but are different $(p<0.05)$ at higher concentrations $(25-200 \mu \mathrm{g} / \mathrm{mL})$ (Figure $1 \mathrm{~b}$ and $1 \mathrm{~d}$ ). However, in all the citrus fruits, the percentage inhibition of sorbitol dehydrogenase was higher than that of aldose reductase.

The $\mathrm{IC}_{50}$ values for the inhibition of aldose reductase and sorbitol dehydrogenase is presented in Table 1. Of all the samples, lime extract has the lowest $\mathrm{IC}_{50}(138.66 \mu \mathrm{g} / \mathrm{mL})$ for aldose reductase
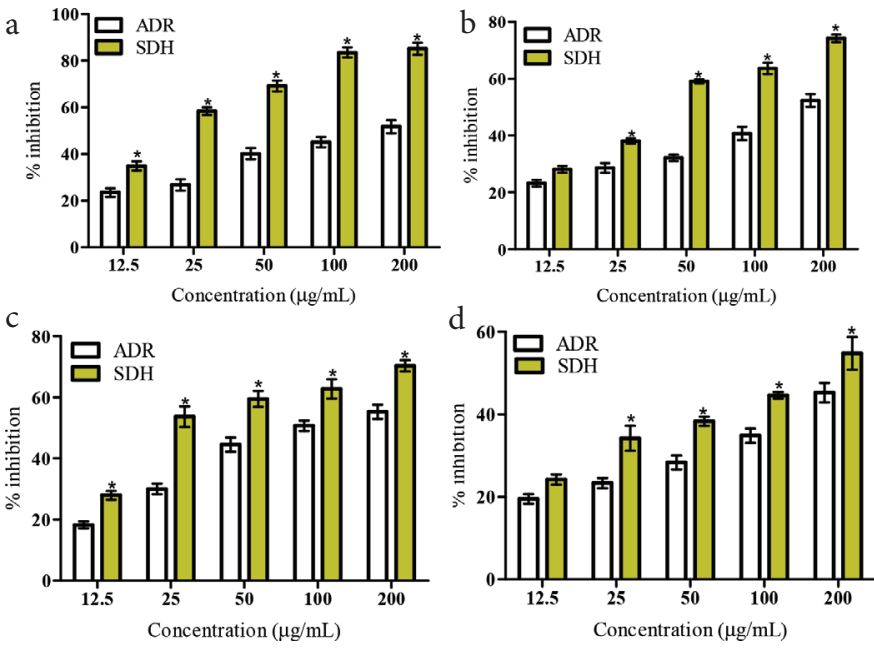

Figure 1 Inhibitory effects of (a) grape (Citrus paradisi) (b) lemon (Citrus limon) (c) lime (Citrus aurantifolia) and (d) orange (Citrus sinensis) fruit extracts on the activities of aldose reductase and sorbitol dehydrogenase. ADR, aldose reductase; $\mathrm{SDH}$, sorbitol dehydrogenase. *Values are significantly different at $p<0.05$.
Table $1 \quad \mathrm{IC}_{50}$ values for the inhibition of aldose reductase and sorbitol dehydrogenase by selected citrus fruits

\begin{tabular}{lcc}
\hline \multirow{2}{*}{ Fruits } & \multicolumn{2}{c}{$\mathrm{IC}_{50}(\boldsymbol{\mu g} / \mathrm{mL})$} \\
\cline { 2 - 3 } & $\begin{array}{c}\text { Aldose } \\
\text { reductase }\end{array}$ & $\begin{array}{c}\text { Sorbitol } \\
\text { dehydrogenase }\end{array}$ \\
\hline Grape (Citrus paradisi) & $169.88 \pm 6.79^{\mathrm{a}}$ & $20.37 \pm 0.76^{\mathrm{a}}$ \\
Lemon (Citrus limon) & $177.42 \pm 5.49^{\mathrm{a}}$ & $65.33 \pm 3.12^{\mathrm{b}}$ \\
Lime (Citrus aurantifolia) & $138.66 \pm 5.81^{\mathrm{b}}$ & $47.21 \pm 0.99^{\mathrm{b}}$ \\
Orange (Citrus sinensis) & $233.34 \pm 12.37^{\mathrm{c}}$ & $161.58 \pm 9.81^{\mathrm{c}}$ \\
Quercetin & $152.20 \pm 8.75^{\mathrm{b}}$ & $67.52 \pm 0.83^{\mathrm{b}}$ \\
\hline The values are expressed as means \pm SEM of triplicate determinations. Means on the same \\
column not sharing common superscript are significantly different $(p<0.05)$ from each other.
\end{tabular}

a

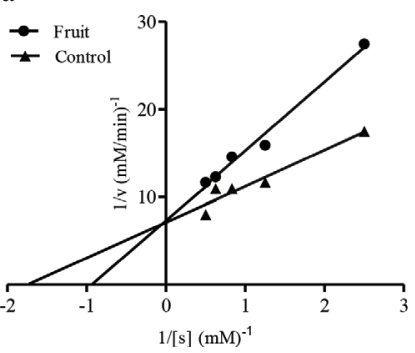

b

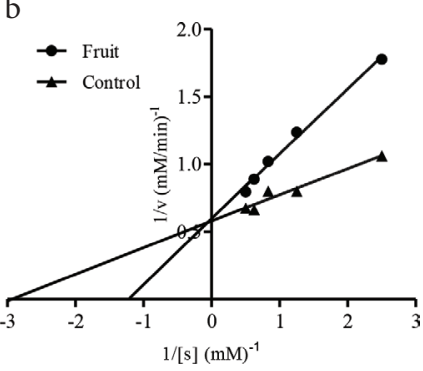

Figure 2 Competitive inhibition of (a) aldose reductase and (b) sorbitol dehydrogenase by Citrus aurantifolia (lime) fruit extract.

Table 2 Enzyme kinetics for the inhibition of aldose reductase and sorbitol dehydrogenase by Citrus aurantifolia (lime) fruit extract

\begin{tabular}{lccc}
\hline Enzyme & Sample & $\boldsymbol{K}_{\mathrm{m}}(\mathbf{m M})$ & $\boldsymbol{V}_{\max }(\mathrm{mM} / \mathbf{m i n})$ \\
\hline Aldose reductase & Control & 0.58 & 0.14 \\
& Lime & 1.06 & 0.13 \\
Sorbitol dehydrogenase & Control & 0.33 & 1.72 \\
& Lime & 0.81 & 1.70 \\
\hline
\end{tabular}

Values presented were obtained from the Double reciprocal plot prepared using GraphPad Prism statistical package.

and is significantly different $(p<0.05)$ to other fruits. However, this value is similar to that of quercetin $(152.20 \mu \mathrm{g} / \mathrm{mL})$. For sorbitol dehydrogenase, grapefruit displayed the lowest IC $_{50}(20.37 \mu \mathrm{g} /$ $\mathrm{mL})$, which is significantly different $(p<0.05)$ to other fruits and quercetin. It is noteworthy to state that lime extract also exhibited a low $\mathrm{IC}_{50}$ value $(47.21 \mu \mathrm{g} / \mathrm{mL})$ for the inhibition of sorbitol dehydrogenase, which is similar to quercetin.

Due to the low $\mathrm{IC}_{50}$ values for the inhibition of aldose reductase and sorbitol dehydrogenase displayed by lime fruit extract, the mode of inhibition of both enzymes by the lime extract was determined. Figure 2 shows that the lime fruit extract inhibited both aldose reductase and sorbitol dehydrogenase in a competitive manner. This is due to the fact that maximum velocities $\left(V_{\max }\right)$ for both the control and lime fruit-inhibited reactions are similar (0.14 and 0.13 $\mathrm{mM} / \mathrm{min}$ for aldose reductase, and 1.72 and $1.70 \mathrm{mM} / \mathrm{min}$ for sorbitol dehydrogenase), while there were elevations in the Michaelis constant $\left(K_{\mathrm{m}}\right)$ of the lime-fruit-inhibited reaction compared to the control (Table 2). 


\section{DISCUSSION}

Diabetes mellitus is a chronic disease with associated complications, and several mechanisms have been proposed for their pathogenesis. These include formation of advanced glycation end products, increased rate of hexosamine pathway, activation of protein kinase $\mathrm{C}$ and increased flux of the polyol pathway [2]. Polyol pathway catalysed by the enzymes, aldose reductase and sorbitol dehydrogenase, has been implicated in many diabetic complications including cataract and kidney disease [15]. While aldose reductase reduces glucose to sorbitol, sorbitol dehydrogenase oxidizes sorbitol to fructose, which eventually elicits diabetic complications.

It has been reported that inhibition of aldose reductase and sorbitol dehydrogenase is an effective strategy of reducing the flux of the polyol pathway [16]. In this study, four citrus fruits (grapefruit, lemon, lime, and orange) were evaluated for their inhibitory effect on the activities of both enzymes. Out of all the extracts tested, lime fruit extract displayed the lowest $\mathrm{IC}_{50}$ value $(138.66 \mu \mathrm{g} / \mathrm{mL})$ for the inhibition of aldose reductase. This is an indication that lime fruit or some of its components could serve as veritable agents for the inhibition of aldose reductase [17]. Aldose reductase is the more important of the two enzymes because it catalyzes the rate-limiting step of the process [6]. The $\mathrm{IC}_{50}$ value for the inhibition of sorbitol dehydrogenase by lime fruit extract is also low and similar to that of the quercetin. This suggests that lime fruit prevents the accumulation of both sorbitol and fructose, thereby shutting down the polyol pathway [15].

Due to the effective inhibition of aldose reductase and sorbitol dehydrogenase by the lime fruit extract, we selected it for the kinetics of inhibition of the enzymes. Double reciprocal plot revealed that lime extract inhibited both aldose reductase and sorbitol dehydrogenase in a competitive manner. This suggests that the active component(s) of the lime fruit extract may have functional group(s) with affinity for active sites of the enzymes [18]. As such, the lime fruit extract compete with the normal substrates for binding to the active sites of the enzymes, thereby forming enzyme-inhibitor complex (EI) instead of enzyme-substrate complex (ES), and preventing catalysis [19]. Once this is accomplished, the polyol pathway does not proceed and the diabetic complications associated with it is mitigated.

Normally, the conversion of glucose to sorbitol causes depletion of $\mathrm{NADPH}$, which is necessary for the regeneration of reduced glutathione, thereby causing oxidative stress [2]. Similarly, $\mathrm{NAD}^{+}$is the cofactor for sorbitol dehydrogenase to produce fructose, leading to redox imbalance. The accumulation of sorbitol and fructose in the cells causes osmotic stress and formation of advanced glycation end product respectively [3]. The competitive inhibition of the activities of both aldose reductase and sorbitol dehydrogenase by the lime fruit extract mitigates this process and ameliorates oxidative stress, osmotic stress and glycation associated with it. Consequently, lime fruit extract will prevent diabetic complications (Figure 3).

Previous studies have reported citrus fruits as rich sources of diverse phytochemicals such as flavonoids, phenolic acids, limonoids, alkaloids, coumarins and essential oils [20]. The presence of these secondary metabolites has been attributed to the antioxidant, anticancer, anti-inflammatory, neuroprotective and antidiabetic properties of these fruits [21]. There is also plethora of studies on the antidiabetic [8,22], hypoglycemic [23,24] and diabetic woundhealing [25] properties of citrus fruits. Lime (C. aurantifolia), also known as sour lime and key lime, is characterized by green thick
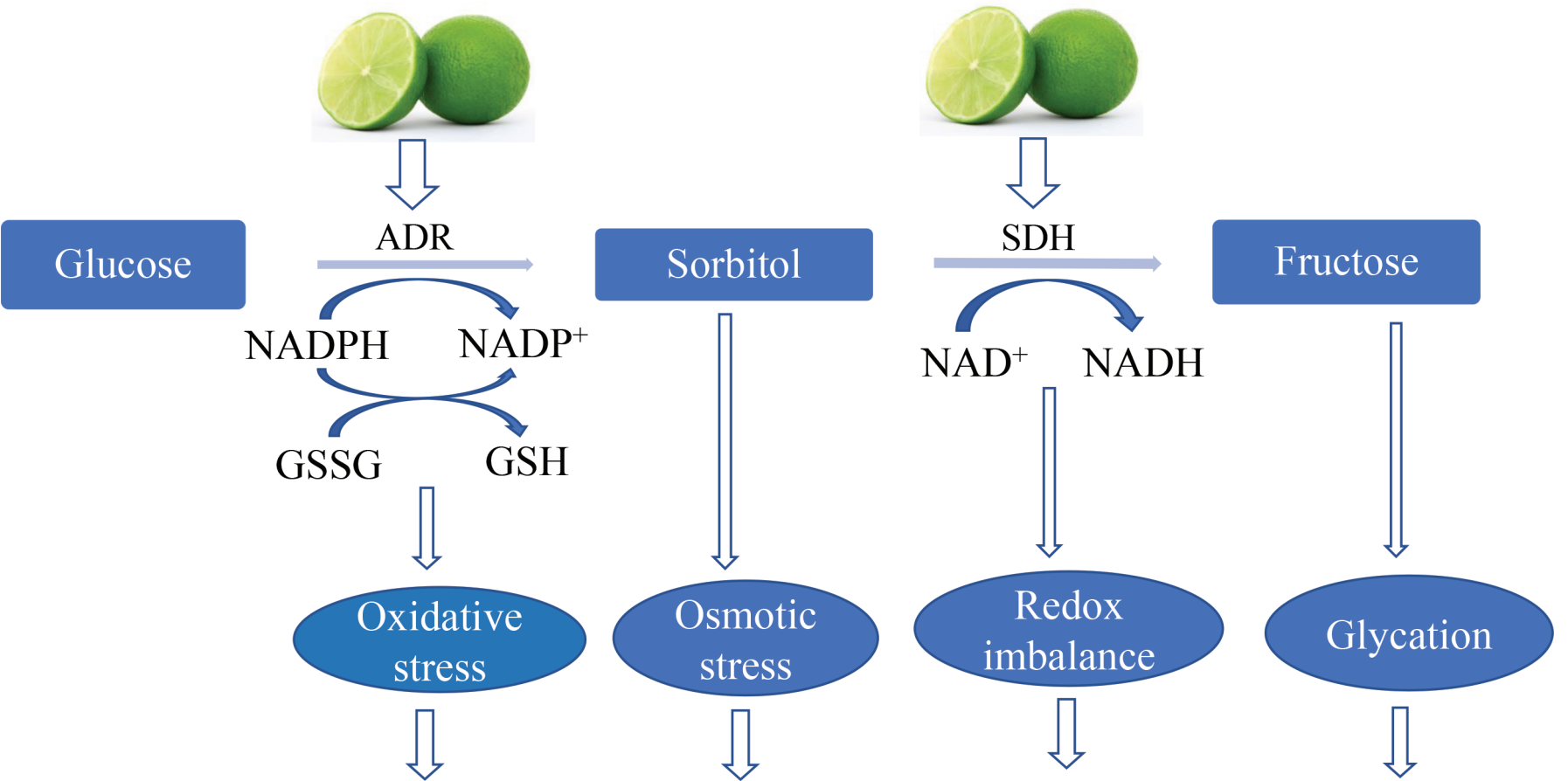

Diabetic complications: Nephropathy, neuropathy, retinopathy

Figure 3 Possible mechanisms involved in the inhibition of polyol pathway enzymes by Citrus aurantifolia (lime) fruit extract, and its amelioration of diabetic complications. ADR, aldose reductase; SDH, sorbitol dehydrogenase; GSH, reduced glutathione; GSSG, glutathione disulfide; NADPH, reduced dicotinamide adenine dinucleotide phosphate; $\mathrm{NAD}^{+}$, nicotinamide adenine dinucleotide. 
peel and pulp poor in juice. While the essential oil from it is used as spice in the food and pharmaceutical industries, the juice is extensively used in the treatment of several diseases including fever, cough, inflammation, infection and obesity [26]. Chemical composition of the fruit juice revealed the presence of several flavonoids (e.g. hesperidin, rutin and didymin) and limonoids (e.g. limonin) [27]. Fruit extract of lime has been found to reduce hyperglycemia via inhibition of pancreatic $\alpha$-amylase activity [28] and ameliorate diabetic complications [29], while its leaf essential oil decreases blood glucose level and increases hepatic glycogen concentration in diabetic rats [30]. This report attests to the ability of lime fruits in the management of diabetes and its complications, through the inhibition of polyol pathway enzymes - aldose reductase and sorbitol dehydrogenase. This bioactive property of lime fruits may be due to the presence of phytochemicals especially flavonoids and limonoids.

\section{CONCLUSION}

It can be concluded that citrus fruits displayed potent inhibition of the activities of polyol pathway enzymes. However, lime fruit elicited most effective inhibition of the activities of aldose reductase and sorbitol dehydrogenase respectively, and the mode of inhibition of both enzymes is the competitive inhibition. Therefore, lime fruit inhibits polyol pathway enzymes, which may contribute to the amelioration of diabetic complications. This may be connected to the presence of flavonoids and limonoids in lime fruit, further study is warranted to characterize the compounds that are responsible for the activity.

\section{CONFLICTS OF INTEREST}

The authors declare they have no conflicts of interest.

\section{AUTHORS' CONTRIBUTION}

MIK and HAB designed the study. TIO, AOB and MAM conducted research and analysed data. MIK and HAB wrote the paper and had primary responsibilities for the final content.

\section{REFERENCES}

[1] International Diabetes Federation. IDF diabetes atlas. 9 ed. Brussels, Belgium: International Diabetes Federation; 2019, p. 168.

[2] Brownlee M. The pathobiology of diabetic complications: a unifying mechanism. Diabetes 2005;54:1615-25.

[3] Lorenzi M. The polyol pathway as a mechanism for diabetic retinopathy: attractive, elusive, and resilient. J Diabetes Res 2007;2007:61038.

[4] Saraswat M, Muthenna P, Suryanarayana P, Mark Petrash J, Bhanuprakash Reddy G. Dietary sources of aldose reductase inhibitors: prospects for alleviating diabetic complications. Asia Pac J Clin Nutr 2008;17:558-65.

[5] Palm F, Hansell P, Ronquist G, Waldenström A, Liss P, Carlsson PO. Polyol-pathway-dependent disturbances in renal medullary metabolism in experimental insulin-deficient diabetes mellitus in rats. Diabetologia 2004;47:1223-31.
[6] Dagher Z, Park YS, Asnaghi V, Hoehn T, Gerhardinger C, Lorenzi M. Studies of rat and human retinas predict a role for the polyol pathway in human diabetic retinopathy. Diabetes 2004;53:2404-11.

[7] Dunlop M. Aldose reductase and the role of the polyol pathway in diabetic nephropathy. Kidney Int 2000;58:S3-S12.

[8] Aruoma OI, Landes B, Ramful-Baboolall D, Bourdon E, Neergheen-Bhujun V, Wagner KH, et al. Functional benefits of citrus fruits in the management of diabetes. Prev Med 2012;54:S12-S16.

[9] Lv X, Zhao S, Ning Z, Zeng H, Shu Y, Tao O, et al. Citrus fruits as a treasure trove of active natural metabolites that potentially provide benefits for human health. Chem Cent J 2015;9:68.

[10] Zou Z, Xi W, Hu Y, Nie C, Zhou Z. Antioxidant activity of Citrus fruits. Food Chem 2016;196:885-96.

[11] Fatmawati S, Ersam T, Shimizu K. The inhibitory activity of aldose reductase in vitro by constituents of Garcinia mangostana Linn. Phytomedicine 2015;22:49-51.

[12] Dongare V, Kulkarni C, Kondawar M, Magdum C, Haldavnekar $\mathrm{V}$, Arvindekar A. Inhibition of aldose reductase and anti-cataract action of trans-anethole isolated from Foeniculum vulgare Mill. fruits. Food Chem 2012;132:385-90.

[13] Kobayashi T, Kaneko T, Iuchi Y, Matsuki S, Takahashi M, Sasagawa I, et al. Localization and physiological implication of aldose reductase and sorbitol dehydrogenase in reproductive tracts and spermatozoa of male rats. J Androl 2002;23:674-83.

[14] Lindstad RI, Teigen K, Skjeldal L. Inhibition of sorbitol dehydrogenase by nucleosides and nucleotides. Biochem Biophy Res Commun 2013;435:202-8.

[15] Chung SSM, Ho ECM, Lam KSL, Chung SK. Contribution of polyol pathway to diabetes-induced oxidative stress. J Am Soc Nephrol 2003;14:S233-S6.

[16] Lee YS, Kim SH, Jung SH, Kim JK, Pan CH, Lim SS. Aldose reductase inhibitory compounds from Glycyrrhiza uralensis. Biol Pharm Bull 2010;33:917-21.

[17] Lim SS, Jung YJ, Hyun SK, Lee YS, Choi JS. Rat lens aldose reductase inhibitory constituents of Nelumbo nucifera stamens. Phytotherapy Res 2006;20:825-30.

[18] Berg JM, Tymoczko JL, Stryer L. Glycolysis and gluconeogenesis. New York: W.H. Freeman and Company; 2002.

[19] Nelson D, Cox M. Lehninger principles of biochemistry. 4th ed. New York: W.H. Freeman and company; 2005.

[20] Goulas V, Manganaris GA. Exploring the phytochemical content and the antioxidant potential of Citrus fruits grown in Cyprus. Food Chem 2012;131:39-47.

[21] Tripoli E, La Guardia M, Giammanco S, Di Majo D, Giammanco M. Citrus flavonoids: molecular structure, biological activity and nutritional properties: a review. Food Chem 2007;104:466-79.

[22] Alu'datt MH, Rababah T, Alhamad MN, Al-Mahasneh MA, Ereifej K, Al-Karaki G, et al. Profiles of free and bound phenolics extracted from Citrus fruits and their roles in biological systems: content, and antioxidant, anti-diabetic and anti-hypertensive properties. Food Funct 2017;8:3187-97.

[23] Kundusen S, Haldar PK, Gupta M, Mazumder UK, Saha P, Bala A, et al. Evaluation of antihyperglycemic activity of Citrus limetta fruit peel in streptozotocin-induced diabetic rats. ISRN Endocrinol 2011;2011:869273.

[24] Menichini F, Tundis R, Loizzo MR, Bonesi M, D’Angelo D, Lombardi P, et al. Citrus medica L. cv Diamante (Rutaceae) peel 
extract improves glycaemic status of Zucker diabetic fatty (ZDF) rats and protects against oxidative stress. J Enzyme Inhib Med Chem 2016;31:1270-6.

[25] Ahmad M, Ansari MN, Alam A, Khan TH. Oral dose of citrus peel extracts promotes wound repair in diabetic rats. Pak J Biol Sci 2013;16:1086-94.

[26] Sandoval-Montemayor NE, García A, Elizondo-Treviño E, Garza-González E, Alvarez L, Del Rayo Camacho-Corona M. Chemical composition of hexane extract of Citrus aurantifolia and anti-Mycobacterium tuberculosis activity of some of its constituents. Molecules 2012;17:11173-84.

[27] Patil JR, Chidambara Murthy KN, Jayaprakasha GK, Chetti MB, Patil BS. Bioactive compounds from Mexican lime (Citrus aurantifolia) juice induce apoptosis in human pancreatic cells. J Agric Food Chem 2009;57:10933-42.

[28] Şeker Karatoprak G, Aşık ÇY, Çakır A, Şafak EK. In vitro pharmacological screening of antioxidant, cytotoxic and enzyme inhibitory activities of Citrus aurantifolia Linn. Dried fruit extract. Int J Environ Health Res 2020;1-10.

[29] Mawarti H, Khotimah, Zulfikar As'ad M, Rajin M. Ameliorative effect of Citrus aurantifolia and Cinnamomum burmannii extracts on diabetic complications in a hyperglycemic rat model. Trop J Pharm Res 2018;17:823-9.

[30] Ibrahim FA, Usman LA, Akolade JO, Idowu OA, Abdulazeez AT, Amuzat AO. Antidiabetic potentials of Citrus aurantifolia leaf essential oil. Drug Res (Stuttg) 2019;69:201-6. 